\title{
Animal Models of Epilepsy
}

\author{
Melda Ateş¹ㅁ, Hilal Harman²(i)
}

\section{EPILEPSY}

Epilepsy is a brain disorder in which normal brain function is impaired. This disorder is characterized by an enduring predisposition to generate recurrent and unpredictable epileptic seizures. These seizures are triggered by neurobiological, cognitive, psychological, and social conditions. Epileptic seizures have been defined as "a transient occurrence of signs and/or symptoms due to abnormal excessive or synchronous neuronal activity in the brain" by International League Against Epilepsy. ${ }^{[2,3]}$

\section{ANIMAL MODELS}

Animal models of epilepsy play an essential role in understanding the pathophysiology of epilepsy. Including in the discovery of new antiepileptic drugs. ${ }^{[4]}$

Epilepsy is not a single disease; it consists of multiple heterogeneous syndromes with various etiologies. Therefore, over 100 models of epilepsy in vitro and in vivo mimic different types of seizures. ${ }^{[5]}$ Most epilepsy and antiepileptic drug studies have been conducted in chemically or electrically stimulated rat and mouse models. ${ }^{[6]}$

'Demiroğlu Bilim University, Faculty of Medicine, Istanbul, Turkey 2Istanbul Gelişim University, Faculty of Nutrition and Dietetics, Istanbul, Turkey

Correspondence: Melda Ateş. Demiroğlu Bilim Üniversitesi Tıp Fakültesi, Psikoloji Bölümü, 34394 Şişli, İstanbul, Türkiye.

E-mail: meldaates@outlook.com

Cite this article as: Ateş M, Harman $\mathrm{H}$. Animal Models of Epilepsy. JEB Med Sci 2020;1(3):113-116.

doi: $10.5606 /$ jebms.2020.75625

Received : October 04, 2020

Accepted : October 27, 2020

Published online : December 29, 2020

@2020 Journal of Experimental and Basic Medical Sciences. All rights reserved.

\begin{abstract}
Epilepsy is one of the most common neurological disorders globally, caused by abnormal excess or synchronous neuronal activity in the brain, causing recurrent seizures. Many studies are carried out to understand the pathophysiology of this disorder and develop anti-seizure drugs. In animals, spontaneous epileptic attacks can be formed by various chemical stimuli and electrical stimulation methods, as well as genetic animal models to mimic the state of epileptic seizures. Providing animal models that are clinically similar to the model of epilepsy in humans is essential in understanding epilepsy and pharmacological studies.

Keywords: Animal models, epilepsy, seizure.
\end{abstract}

An Ideal model of epilepsy should show these characteristics:

- Formation of spontaneous and recurrent seizures,

- Clinically, it offers a type of seizure similar to seizures that occur in human epilepsy,

- The onset of age-related epilepsy, similar to epileptic syndromes in humans,

- Clinical seizures show epileptic EEG activity similar to that observed in humans,

- Pharmacokinetic display of Antiepileptic drugs similar to those in humans (allows the preservation of effective drug doses during chronic treatment)

- Effective plasma concentrations of antiepileptic drugs similar to those required to control the relevant type of seizure in humans. ${ }^{[6]}$

Seizure models are often produced by chemically delivering convulsant substances or electrically stimulating specific brain areas. Seizures caused by this stimulation can be observed both behaviorally and electrographically. ${ }^{[7]}$ 
Different animal models are used to create various forms of human epilepsy. For example, pentylenetetrazole (PTZ)-induced convulsions mimic absence epilepsy models, while maximal electroshock (MES)-induced seizures represent generalized tonic-clonic epilepsy seizures in humans. ${ }^{[7,8]}$

\section{CHEMICAL MODELS}

\section{Kainic Acid Model}

Kainic acid is a potent amino acid agonist that activates glutamate receptors. Glutamate acts with ionotropic (NMDA, AMPA, and kainate receptors) and metabotropic receptors and plays an important role in initiating, propagating, and maintaining epileptic activity. ${ }^{[9,10]}$ The Epilepsy model created by kainic acid is one of several models used to study temporal lobe epilepsy. All five subtypes of kainic acid receptors are commonly found in the hippocampus. After the injection of kainic acid, damage occurs to the hippocampus, amygdala, piriform cortex, entorhinal cortex, septum, and medial thalamus, always symmetrical. ${ }^{[11-13]}$

A depth electrode is implanted in the hippocampus while two surface electrodes are placed in the animal's cortex and cerebellum to receive continuous EEG recording. 0.4-0.8 $\mu \mathrm{g}$ kainic acid is used in intraventricular applications, $8-12 \mathrm{mg} / \mathrm{kg}$ in subcutaneous (s.c), and intraperitoneal (i.p) applications, and 1-2 $\mu \mathrm{g}$ in intraparenchymal applications used for creating epilepsy model in rats. Administration of $20-40 \mathrm{mg} / \mathrm{kg}$ (i.p. kainic acid is preferred in mice. ${ }^{[12,14]}$

Seizures usually begin to occur in the first hours of injection and can be observed for up to 6 hours. Seizures are observed according to the Racine classification. These phases are;

(0) no seizure observed,

(1) mouth and face movements, shaking of whiskers,

(2) head nodding,

(3) forelimb clonus, myoclonic jerks

(4) rearing, tonic seizure

(5) rearing, tonic-clonic seizure, faltering and falling,

(6) and death. ${ }^{[12,15]}$

\section{Pentylenetetrazole (PTZ) Model}

PTZ (metrazole) is a chemical antagonist of the GABAA receptor that causes severe convulsions when applied to animals. The most widely used animal model to study the effects of new anticonvulsant substances is the phenomenon of kindling with PTZ. ${ }^{[7,16]}$

PTZ can be used to build animal models of both acute and chronic epilepsy. For example, in the threshold dose to rodents, 60 to $100 \mathrm{mg} / \mathrm{kg}$ intraperitoneal (i.p.), or subcutaneous (s.c) acute PTZ injection causes myoclonic jerks, clonus, and tonic extension. Below the threshold dose, 20 to $40 \mathrm{mg} / \mathrm{kg}$ of PTZ i.p. repeated application, might trigger chronically self-occurring seizures (kindling phenomenon). ${ }^{[7]}$

A second dose of $20 \mathrm{mg} / \mathrm{kg}$ is administered 10 minutes after the first administration of $40 \mathrm{mg} / \mathrm{kg}$ intraperitoneal PTZ to create status epilepticus in rats. Then $10 \mathrm{mg} / \mathrm{kg}$ of PTZ is injected intraperitoneally every 10 minutes until the status model occurs. It is characterized by loss of posture and the observation of tonic-clonic seizures. ${ }^{[17]}$

\section{Pilocarpine Model}

The pilocarpine model is one of the models commonly used to study temporal lobe epilepsy. Pilocarpine, an acetylcholine receptor agonist, acts by cholinergic hyperactivation by activating muscarinic receptors. ${ }^{[18,19]}$

Usually, $1 \mathrm{mg} / \mathrm{kg}$ of scopolamine metal nitrate 30 minutes before pilocarpine administration is injected s.c. to reduce cholinergic action's peripheral effects. Then $350-385 \mathrm{mg} / \mathrm{kg}$ of pilocarpine is injected intraperitoneally. If status epilepticus is not observed in the rat, the first dose is $110 \mathrm{mg} / \mathrm{kg}$, followed by additional doses of $60 \mathrm{mg} / \mathrm{kg}$ i.p. until it occurs. ${ }^{[20,21]}$

Rats begin to develop electrographic and behavioral seizures, lasting for several hours, approximately 45 minutes after pilocarpine injection. Behavioral seizures can be monitored according to the Racine classification. ${ }^{[21]}$

\section{ELECTRICAL STIMULATION MODELS}

\section{Maximal Electroshock (MES) Model}

It is applied with alternating current at $50-60 \mathrm{~Hz}$ or lower frequency $(6 \mathrm{~Hz})$ with corneal, head, or ear electrodes. The current is $50 \mathrm{~mA}$ in the mouse and $150 \mathrm{~mA}$ in the rat. Electroshock seizures are loss of posture, tonic extension, and clonus following tonic flexion. The most crucial point of the model is the end seizure in the form of a tonic extension to the posterior, parallel to the body horizontal in the front and back limbs. ${ }^{[22]}$ This model may not give very 
accurate results, as it gives negative results in drugs with different mechanisms, such as levetiracetam, tiagabine, or vigabatrin. ${ }^{[23]}$

\section{Kindling Model}

Kindling, one of the commonly used models of chronic temporal lobe epilepsy(TLE), ${ }^{[24]}$ also causes behavioral changes similar to the various emotional problems observed in patients with TLE. ${ }^{[25]}$ One of the convenience shown by this model is that the epileptogenesis process is well known, easily controlled, and measured without errors. TLE's electrical kindling model is based on daily repetitive electrical stimulation of amygdaloid nuclei, piriform cortex, hippocampus, or other limbic structures. ${ }^{[26,27]}$

In this model, subjects are exposed to daily electrical stimulation, and seizure formation may develop in the amygdaloid, the region most sensitive to kindling formation, resulting from repeated arousal. ${ }^{[22,24]}$ It reveals electrical stimulation in the Kindling model that initially produces short, low-frequency electrographic discharges without behavioral response. Long, high-frequency discharges occur when repeated electrical stimulation over several days has a strong convulsive reaction. ${ }^{[28-30]}$ After a few days of kindling, the subject begins to experience complex seizures. The progression from simple partial seizures to complex seizures is most pronounced in the brain structure surrounding the amygdala, although it is visible with stimulation in all limbic and forebrain regions. ${ }^{[3]]}$

\section{Status Epilepticus Model}

The SE model can be created in animals by chemical substances (by systemic application of kainic acid or pilocarpine) and electrical stimulation. ${ }^{[23]}$ Mazarati and colleagues ${ }^{[33]}$ have shown that the self-developing status epilepticus model in rats can also be stimulated by intermittent electrical stimulation. This SE induction method has a high survival rate $(90-100 \%)$ if stimulation times are less than 60 Minutes. It has also been shown that SE-induced epilepsy can be improved in already kindling animals either by performing 60-minute high-frequency stimulation of the basolateral amygdala ${ }^{[34,35]}$ or by pilocarpine injections. ${ }^{[36]}$

\section{GENETIC MODELS}

Genetic absence epilepsy rats from Strasbourg (GAERS) are a genetic pattern of absence seizures developed by Wistar rat colonies, exhibiting spontaneous spikes, and wave discharges (SWDs). They were similarly discovered when the Wistar Albino Glaxo (WAG/Rij) species was born and suffered an absence seizure. ${ }^{[37-39]}$ The frequency of seizures in the GAERS strain is greater than in the WAG/Rij rats; the previous absence seizure lasts on average about 15-20 times every minute and hour. Both genetic models offer high predictability for investigating the absence and adverse effects of antiepileptic drugs. Studies on these models show that thalamocortical circuits are the critical manufacturer of absence seizures. ${ }^{[40]}$

\section{Conclucision}

Epilepsy is a heterogeneous disorder in which various etiologies play a role, and the pathophysiology is not entirely known. Many methods can be used in experimental studies aimed at understanding this condition and preventing seizures. In creating an epilepsy model in animals, it is crucial that seizures are clinically, electrographically, and behaviorally similar to humans. Furthermore, episodes occur spontaneously, and antiepileptics can show pharmacological effects similar to that in humans. Experiments created with ideal models shed light on this disorder.

\section{Declaration of conflicting interests}

The authors declared no conflicts of interest with respect to the authorship and/or publication of this article.

\section{Funding}

The authors received no financial support for the research and/or authorship of this article.

\section{REFERENCES}

1. Li G, Bauer S, Nowak M, Norwood B, Tackenberg B, Rosenow F, et al. Cytokines and epilepsy. Seizure 2011;20:249-56.

2. Fisher RS, van Emde Boas W, Blume W, Elger C, Genton $P$, Lee $P$, et al. Epileptic seizures and epilepsy: definitions proposed by the International League Against Epilepsy (ILAE) and the International Bureau for Epilepsy (IBE). Epilepsia 2005;46:470-2.

3. Fisher RS, Acevedo C, Arzimanoglou A, Bogacz A, Cross $\mathrm{JH}$, Elger $\mathrm{CE}$, et al . ILAE official report: a practical clinical definition of epilepsy. Epilepsia 2014;55:475-82.

4. Rogawski MA. Molecular targets versus models for new antiepileptic drug discovery. Epilepsy Res 2006;68:22-8.

5. Raol YH, Brooks-Kayal AR. Experimental models of seizures and epilepsies. Prog Mol Biol Transl Sci 2012;105:57-82.

6. Löscher W, Schmidt D. Which animal models should be used in the search for new antiepileptic drugs? A proposal 
based on experimental and clinical considerations. Epilepsy Res 1988;2:145-81.

7. Dhir A. Pentylenetetrazol (PTZ) kindling model of epilepsy. Curr Protoc Neurosci 2012;58:9-37.

8. De Deyn PP, D'Hooge R, Marescau B, Pei YQ. Chemical models of epilepsy with some reference to their applicability in the development of anticonvulsants. Epilepsy Res 1992;12:87-110.

9. Lévesque $M$, Avoli $M$. The kainic acid model of temporal lobe epilepsy. Neurosci Biobehav Rev 2013;37:2887-99.

10. Brodie MJ, Besag F, Ettinger AB, Mula M, Gobbi G, Comai $S$, et al. Epilepsy, antiepileptic drugs, and aggression: an evidence-based review. Pharmacol Rev 2016;68:563-602.

11. Vogel HG, editor. Drug discovery and evaluation: pharmacological assays. New York: Springer Science \& Business Media; 2002.

12. Goodman, J. H. (1998). Experimental models of status epilepticus. Neuropharmacology methods in epilepsy research, 1, 95-125.

13. RaoMS, HattiangadyB, ReddyDS, ShettyAK. Hippocampal neurodegeneration, spontaneous seizures, and mossy fiber sprouting in the F344 rat model of temporal lobe epilepsy. J Neurosci Res 2006;83:1088-105.

14. Ben-Ari $Y$, Tremblay E, Riche D, Ghilini G, Naquet R. Electrographic, clinical and pathological alterations following systemic administration of kainic acid, bicuculline or pentetrazole: metabolic mapping using the deoxyglucose method with special reference to the pathology of epilepsy. Neuroscience 1981;6:1361-91.

15. Racine RJ. Modification of seizure activity by electrical stimulation. II. Motor seizure. Electroencephalogr Clin Neurophysiol 1972;32:281-94.

16. Orloff MJ, Williams HL, Pfeiffer CC. Timed intravenous infusion of metrazol and strychnine for testing anticonvulsant drugs. Proc Soc Exp Biol Med 1949;70:254-7.

17. Erdoğan F, Gölgeli A, Arman F, Ersoy AO. The effects of pentylenetetrazole-induced status epilepticus on behavior, emotional memory, and learning in rats. Epilepsy Behav 2004;5:388-93.

18. Hamilton SE, Loose MD, Qi M, Levey Al, Hille B, McKnight $\mathrm{GS}$, et al. Disruption of the $\mathrm{m} 1$ receptor gene ablates muscarinic receptor-dependent $M$ current regulation and seizure activity in mice. Proc Natl Acad Sci U S A 1997;94:13311-6.

19. Luby M, Spencer DD, Kim JH, deLanerolle N, McCarthy G. Hippocampal MRI volumetrics and temporal lobe substrates in medial temporal lobe epilepsy. Magn Reson Imaging 1995;13:1065-71.

20. Arida RM, Scorza FA, Peres CA, Cavalheiro EA. The course of untreated seizures in the pilocarpine model of epilepsy. Epilepsy Res 1999;34:99-107.

21. Goffin K, Nissinen J, Van Laere K, Pitkänen A. Cyclicity of spontaneous recurrent seizures in pilocarpine model of temporal lobe epilepsy in rat. Exp Neurol 2007;205:501-5.

22. Bambal G, Çakıl D, Ekici F. Models of experimental epilepsy. J Clin Exp Invest 2011;2:118-23.

23. Garcia Garcia ME, Garcia Morales I, Matías Guiu J. Experimental models in epilepsy. Neurologia
2010;25:181-8.

24. Schwartzkroin PA, Moshé SL, Pitkänen A. Models of seizures and epilepsy. Massachusetts: Academic Press; 2006.

25. Kalynchuk LE, Pinel JP, Meaney MJ. Serotonin receptor binding and mRNA expression in the hippocampus of fearful amygdala-kindled rats. Neurosci Lett 2006;396:38-43.

26. Carçak N, Ferrandon A, Koning E, Aker RG, Ozdemir O, Onat FY, et al. Effect of stage 2 kindling on local cerebral blood flow rates in rats with genetic absence epilepsy. Epilepsia 2009;50:33-43.

27. Engel J, Pedley TA, Aicardi J, Dichter MA. Epilepsy: A Comprehensive Textbook. Vol 1. 2nd ed. Philadelphia: Lippincott Williams \& Wilkins; 2008.

28. Goddard GV, Mclntyre DC, Leech CK. A permanent change in brain function resulting from daily electrical stimulation. Exp Neurol 1969;25:295-330.

29. Mclntyre DC. Differential amnestic effect of cortical vs. amygdaloid elicited convulsions in rats. Physiol Behav 1970;5:747-53.

30. Mclntyre DC, Saari M, Pappas BA. Potentiation of amygdala kindling in adult or infants rats by injections of 6-hydroxydopamine. Exp Neurol 1979;63:527-44.

31. Rolston JD, Desai SA, Laxpati NG, Gross RE. Electrical stimulation for epilepsy: experimental approaches. Neurosurg Clin N Am 2011;22:425-42.

32. Dudek FE, Hellier JL, Williams PA, Ferraro DJ, Staley KJ. The course of cellular alterations associated with the development of spontaneous seizures after status epilepticus. Prog Brain Res 2002;135:53-65.

33. Mazarati AM, Wasterlain CG, Sankar R, Shin D. Self-sustaining status epilepticus after brief electrical stimulation of the perforant path. Brain Res 1998;801:251-3.

34. Mclntyre DC, Nathanson D, Edson N. A new model of partial status epilepticus based on kindling. Brain Res 1982;250:53-63.

35. Mclntyre DC, Stokes KA, Edson N. Status epilepticus following stimulation of a kindled hippocampal focus in intact and commissurotomized rats. Exp Neurol 1986;94:554-70.

36. Buterbaugh GG, Michelson HB, Keyser DO. Status epilepticus facilitated by pilocarpine in amygdalakindled rats. Exp Neurol 1986;94:91-102.

37. Amirnovin R, Williams ZM, Cosgrove GR, Eskandar EN. Experience with microelectrode guided subthalamic nucleus deep brain stimulation. Neurosurgery 2006;58(1 Suppl):ONS96-102.

38. van Luijtelaar EL, Coenen AM. Two types of electrocortical paroxysms in an inbred strain of rats. Neurosci Lett 1986;70:393-7.

39. Vergnes M, Marescaux C, Micheletti G, Reis J, Depaulis A, Rumbach L, et al. Spontaneous paroxysmal electroclinical patterns in rat: a model of generalized non-convulsive epilepsy. Neurosci Lett 1982;33:97-101.

40. Danober L, Deransart C, Depaulis A, Vergnes M, Marescaux C. Pathophysiological mechanisms of genetic absence epilepsy in the rat. Prog Neurobiol 1998;55:27-57. 